\title{
ARKKITEHDIN LUURANKOTANSSI
}

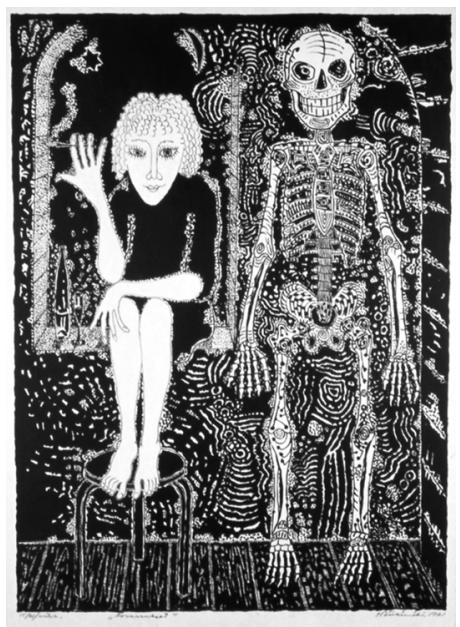

Heimo Riihimäki: Toverukset, 1961, litografia,

harmaanvihreä paperi, 56,5 x $41 \mathrm{~cm}$. Valokuva: Oliver Whitehead.

Heimo Riihimäen (1907-1962) elämänura jakautui arkkitehtuurin ja kuvataiteen kesken. Arkkitehtina hänet tunnetaan ehkä parhaiten yhtenä kolmesta arkkitehtiopiskelijasta, jotka onnistuivat 1936 toteuttamaan hullun rohkean ehdotuksensa väliaikaiseksi linja-autoasemaksi, basaarirakennukseksi ja huoltoasemaksi entisen Turun kasarmin paikalle Mannerheimintien varrelle Helsingin keskustaan. Lasipalatsi - Niilo Kokon, Viljo Revellin ja Riihimäen suunnittelema funktionalistinen liikekeskus - ilmensi modernin arkkitehtuurikäsityksen dynaamisuutta, läpinäkyvyyttä ja keveyttä.

Arkkitehtina Riihimäki jatkoi suunnittelemalla yksin ja yhdessä Revellin ja Erkki Huttusen kanssa asuinkerrostaloja Töölöön. Vaimonsa runonlausuja Kastehelmi Karjalaisen kanssa hän muutti 1939 piirtämäänsä taloon Mechelinin- ja Töölönkadun kulmassa. Sattumien kautta nuoren parin huoneistosta piirtyi elävä kuva Helvi Hämäläisen kohutun romaanin Säädyllinen murhenäytelmä lukuun "Eräs aamupäivä", jossa kerrotaan vierailusta arkkitehdin asunnossa. Funktionalistisen liikepalatsin ideoita Riihimäki kehitteli 1940 valmistuneessa Osuusliike Imatran näyttävässä Väärän talossa, joka käsitti kauppatilojen lisäksi kaksi ravintolaa ja hotellin. Sodan aikana hän toimi Käkisalmessa mutta pääasiassa Kotkan kaupunginarkkitehtina suunnitellen pientaloja, asuinkerrostaloja, vedenpuhdistamon ja tehden kaavoitustöitä. Myöhemmin hän työskenteli Turun kaupungin palveluksessa.

Sota pakotti Riihimäen maalarinintohimon esille, eikä hän enää jaksanut yhtä innostuneesti kuin ennen tarttua arkkitehtuurin haasteisiin. Ammatin rutiinit taisivat tympiä häntä. Vuodesta 1946 alkaen hänen ekspressiivisiä guassimaalauksiaan oli esillä erityisesti Turun ja Helsingin gallerioissa. Väri oli Riihimäelle muotoa ja rakennetta tärkeämpi, ja vähitellen hänen maalauksensa alkoivat kehittyä purkauksenomaisesta suoruudesta surrealismin ja informalismin suuntaan. Vuosikymmenessä hän loi itselleen johtavien päivälehtien kriitikoiden tunnustaman aseman maalarina.

Sairastuminen leukemiaan 1950-luvun lopulla kiihdytti taiteilijan työskentelyn tempoa. Parina viimeisenä elinvuotenaan Riihimäellä oli useita näyttelyitä, hänen ehdotuksensa Eduskuntatalon seinämaalauskilpailussa lunastettiin, ja hän omaksui uuden ilmaisuvälineen: litografian. "Kokonaan uutta tuotannossa ovat kivipiirrokset, jotka liikkuvat kuoleman ajatuksen ympärillä. Ne eivät kuitenkaan ole järkyttäviä vaan pikemminkin kuin satukuvia, joita tosin sävyttää irtonainen hirtehishuumori. Joskus kun eri tekijät ovat sulautuneet eheästi kokonaisuudeksi saa kuvaus myös runouden hohdetta kuten Vanhassa kuolemassa, joka tuo mieleen Olavi Paavolaisen nuoruuden runot lempeästä kuolemasta, jonka suhde luontoon on ystävällisen inhimillinen. Tuntuu kuin taiteilija näissä puolittain kertovissa ja piirretyissä töissään olisi löytänyt lopulta oikean muodon sille leikkivälle fantasialle, joka oli hänen taiteensa pontimena. Ne samoin kuin viimeiset isot maalaukset ovat epäilemättä huomattavinta hänen taiteellisessa tuotannossaan, joka siis katkesi elinvoimaisimmassa vaiheessaan”, E. J. Vehmas arvioi Uudessa Suomessa 17.2.1963.

Heimo Riihimäki oli enoni. 